\title{
Gambaran Bakteri Pada Ikan Haruan (Channa striata) Yang Dijual Di Pasar Kota Pangkalan Bun
}

\author{
${ }^{1}$ Iqlila Romaidha \\ ${ }^{1}$ Stikes Borneo Cendekia Medika Pangkalan Bun \\ ${ }^{1}$ Email : iqlilaromaidha@yahoo.co.id
}

\begin{abstract}
ABSTRAK
Ikan gabus/ ikan haruan (Channa striata) merupakan jenis ikan yang bernilai ekonomis. Di Indonesia penyebarannya antara lain di Sumatera, Jawa, Kalimantan, Sulawesi, dan Papua. Spesies ini memiliki rasa yang khas, tekstur daging tebal dan putih sehingga harganya pun cukup mahal baik dalam bentuk segar maupun kering (ikan asin). Selain itu, memiliki kandungan albumin yang diperlukan tubuh manusia dalam mengatasi berbagai penyakit terutama yang disebabkan berkurangnya jumlah protein darah (Andriyanto, 2009). C. striata banyak dijual di pasar Pangkalan Bun, masyarakat biasanya mengolah $C$. striata Sebagai lauk yang dimasak merah dipadukan dengan nasi kuning atau dijadikan krupuk. C. striata dapat mengalami penyakit yang secara dibedakan menjadi 2 kelompok yaitu penyakit infeksius dan noninfeksius. Pertama, penyakit non-infeksius biasanya disebabkan, defisiensi nutrisi, atau abnormalitas genetis. Penelitian ini bertujuan untuk Mengetahui gambaran bakteri pada $C$. striata yang dijual di pasar Pangkalan Bun. Parameter Pengamatan dan Analisa Data Parameter yang diamati yaitu gejala klinis eksternal dan internal pada ikan. Hasil Hasil penelitian menunjukkan bakteri yang teridentifikasi pada sampel komoditas ikan air tawar di dominasi oleh bakteri Aeromonas hydrophila, Pseudomonas sp. dan Streptococcus sp.
\end{abstract}

Kata Kunci : Channa striata, albumin, Aeromonas hydrophila, Pseudomonas sp., Streptococcus $\mathrm{sp}$

\section{IDENTIFICATION ESCHERICHIA COLI BACTERIA IN ICE TEA AROUND STIKES BCM PANGKALAN BUN KOTAWARINGIN BARAT}

ABSTRACT

Cork fish / haruan fish (Channa striata) is a type of fish that has economic value. In Indonesia, the distribution is in Sumatra, Java, Kalimantan, Sulawesi and Papua. This 
species has a distinctive taste, thick and white meat texture, so the price is quite expensive both in the form of fresh or dried (salted fish). In addition, it has the albumin content needed by the human body in overcoming various diseases, especially those caused by reduced amounts of blood protein (Andriyanto, 2009). C. striata is widely sold in the Pangkalan Bun market, people usually process $C$. striata. As a side dish cooked in red mixed with yellow rice or made into crackers. $C$. striata can experience diseases that are divided into 2 groups, namely infectious and non-infectious diseases. First, non-infectious diseases are usually caused by nutritional deficiencies, or genetic abnormalities. This study aims to determine the picture of bacteria in C. striata which are sold in the Pangkalan Bun market. Observation Parameters and Data Analysis The parameters observed were external and internal clinical symptoms in fish. Results The results showed that bacteria identified in the sample of freshwater fish commodities were dominated by Aeromonas hydrophila, Pseudomonas sp. and Streptococcus sp.

Keywords: Channa striata, albumin, Aeromonas hydrophila, Pseudomonas sp., Streptococcus sp.

\section{PENDAHULUAN}

Ikan gabus/ ikan haruan (Channa striata) merupakan jenis ikan yangang bernilai ekonomis. Di Indonesia penyebarannya antara lain di Sumatera, Jawa, Kalimantan, Sulawesi, dan Papua. Spesies ini memiliki rasa yang khas, tekstur daging tebal dan putih sehingga harganya pun cukup mahal baik dalam bentuk segar maupun kering (ikan asin). Selain itu, memiliki kandungan albumin yang diperlukan tubuh manusia dalam mengatasi berbagai penyakit terutama yang disebabkan berkurangnya jumlah protein darah (Andriyanto, 2009). C. striata banyak dijual di pasar Pangkalan Bun, masyarakat biasanya mengolah $C$. striata Sebagai lauk yang dimasak merah dipadukan dengan nasi kuning atau dijadikan krupuk.

C. striata ini termasuk salah satu jenis ikan karnivora air tawar dikarenakan sifatnya yang memangsa ikan-ikan kecil sebagai pakannya. $C$. striata dapat mengalami penyakit yang secara dibedakan menjadi 2 kelompok yaitu penyakit infeksius dan noninfeksius. Pertama, penyakit noninfeksius biasanya disebabkan, defisiensi nutrisi, atau abnormalitas genetis. Pada budidaya ikan dikenal pula istilah hama, dan kelompok ini termasuk dalam penyakit non-infeksius. Kedua, penyakit infeksius disebabkan oleh organisme patogen yang ada dalam lingkungan atau terbawa oleh media pembawa lain. Lebih detail, kelompok penyakit ini dibedakan menjadi 4 
golongan, yaitu penyakit parasitik, mikotik, viral dan bakterial (Dinlutkan, 2017).

Penyakit infeksius maupun non infeksius mengganggu produktivitas ikan selain itu apabila dalam pengolahan $C$. striata tidak tepat dikhawatirkan menyebabkan penyakit bagi konsumen. Pada penelitian ini dilakukan tentang gambaran bakteri pada C. striata yang dijual di pasar Pangkalan Bun supaya dapat diketahui bakteri apa yang mengkontaminasi, sehingga dapat dilakukan pencegahan dalam mengkonsumsi $C$. striata

C. striata merupakan salah satu jenis ikan karnivora air tawar yang menghuni kawasan Asia Tenggara, namun belum banyak diketahui tentang sejarah dan sifat biologisnya. Ikan jenis ini dikenal sebagai ikan konsumsi dan banyak ditemui di pasaran. Dalam ukuran kecil (anakan) ikan gabus terlihat eksotis sehingga banyak dimanfaatkan sebagai ikan hias dalam akuarium.Di Indonesia, ikan ini dikenal dengan banyak nama daerah yaitu aruan, haruan (Malaysia, Banjarmasin, Banjarnegara), kocolan (Betawi), bogo (Sidoarjo), bayong, licingan (Banyumas), kutuk (Jawa).
Morfologi Tubuh ikan gabus umumnya berwarna coklat sampai hitam pada bagian atas dan coklat muda sampai keputihputihan pada bagian perut. Kepala agak pipih dan bentuknya seperti ular dengan sisik-sisik besar di atas kepala, oleh sebab itu, dijuluki sebagai "snake head". Sisi atas tubuh ikan gabus dari kepala hingga ke ekor berwarna gelap, hitam kecoklatan atau kehijauan. Sisi bawah tubuh berwarna putih mulai dagu ke belakang. Sisi samping bercoret tebal (striata, bercoret-coret) dan agak kabur, warna tersebut seringkali menyerupai lingkungan sekitarnya. Mulut ikan gabus besar, dengan gigi-gigi yang tajam. Sirip punggung memanjang dengan sirip ekor membulat di bagian ujungnya.

Habitat Ikan gabus umumnya didapati pada perairan dangkal seperti sungai dan rawa dengan kedalaman 40 $\mathrm{cm}$ dan cenderung memilih tempat yang gelap, berlumpur, berarus tenang, ataupun wilayah bebatuan untuk bersembunyi. Selain itu, spesies ini juga ditemui di danau serta saluransaluran air hingga ke sawah-sawah. Day (1967) dalam Tjahjo \& Purnomo (1998) menyatakan bahwa ikan gabus termasuk salah satu jenis ikan air tawar yang 
mempunyai penyebaran yang luas, dan secara alami dapat hidup di danau, sungai, rawa air tawar, dan sawah. Sedangkan menurut Muflikhah (2007) benih ikan gabus banyak ditemukan di daerah perairan yang banyak rerumputan atau tanaman air dan belukar yang terendam air.

\section{A. Penyakit Bakterial (Bacterial Disease)} (Dinlutan, 2017).

1. Penyakit Merah (Motile Aeromonas Septicemia)

a. Penyebab Aeromonas hydrophila

b. Karakteristik patogen

Penyakit Merah merupakan penyakit bakterial yang sering terjadi pada semua umur dan jenis ikan air tawar, meskipun jenis bakteri tersebut sering pula ditemukan pada ikan air payau dan laut;

c. Infeksi bakteri ini biasanya berkaitan dengan kondisi stress akibat: kepadatan tinggi, malnutrisi, penanganan yang kurang baik, infeksi parasit, bahan organik tinggi, oksigen rendah, kualitas air yang buruk, fluktuasi suhu air yang ekstrim. Serangan bersifat akut, dan apabila kondisi lingkungan terus merosot, kematian yang ditimbulkannya bisa mencapai $100 \%$.

d. Gejala Klinis : Warna tubuh kusam/gelap, nafsu makan menurun, mengumpul dekat saluran pembuangan, kulit kasat, dan ekses lender; - Perdarahan pada pangkal sirip, ekor, sekitar anus dan bagian tubuh lainnya: Sisik lepas, luka di sekitar mulut, dan bagian tubuh lainnya. - Pada infeksi berat, perut lembek dan bengkak (dropsy) yang berisi cairan merah kekuningan; - Ikan mati lemas sering ditemukan di permukaan maupun dasar kolam.

\section{Columnaris Disease}

a. Penyebab Flavobacterium columnare atau Fexibacterium columnare

b. Karakteristik patogen: Bakteri gram negatif, berbentuk batang kecil, bergerak meluncur, dan terdapat di ekosistem air tawar. Sifat bakteri ini adalah berkelompok membentuk kumpulan seperti column.

c. Infeksi bakteri ini umumnya berkaitan dengan kondisi stress akibat: fluktuasi suhu air yang 
ekstrim dan kualitas air yang buruk. -Serangan sering terjadi pada kelompok ikan pasca transportasi. Sifat serangan umumnya sub akut - akut, apabila insang yang dominan sebagai target organ, ikan akan mati lemas dan kematian yang ditimbulkannya bisa mencapai $100 \%$

d. Gejala klinis - Luka di sekitar mulut, kepala, badan atau sirip. Luka berwarna putih kecoklatan kemudian berkembang menjadi borok. - Infeksi di sekitar mulut, terlihat seperti diselaputi benang (thread-like) sehingga sering disebut penyakit "jamur mulut". Di sekeliling luka tertutup oleh pigmen berwarna kuning cerah. Apabila menginfeksi insang, kerusakan dimulai dari ujung filamen insang dan merambat ke bagian pangkal, akhirnya filamen membusuk dan rontok (gill rot).

3. Penyakit Streptococciasis

a. Penyebab Streptococcus agalactiae, S. iniae

b. Karakteristik patogen: Bakteri gram positif, berbentuk bulat kecil (cocci), bergabung menyerupai rantai, nonmotil, koloni transparan dan halus.

c. Infeksi Streptococcus iniae sering terjadi pada budidaya ikan air laut; sedangkan S. agalactiae lebih banyak ditemukan pada ikan budidaya air tawar.

d. Pola serangan kedua jenis bakteri tersebut umumnya bersifat kronik - akut. Jenis ikan air laut yang sering dilaporkan terkena penyakit streptococciasis adalah kakap dan kerapu, sedangkan pada ikan air tawar adalah ikan nila. - Target organ infeksi Streptococcus spp. banyak ditemukan di otak dan mata, sehingga disebut "syndrome meningoencephalitis dan panophthalmitis", dan ikan yang terinfeksi sering menunjukkan tingkah laku abnormal seperti kejang atau berputar serta mata menonjol (exopthalmus). Penyakit ini sering dilaporkan pada sistem budidaya intensif, lingkungan perairan tenang (stagnant) dan/atau sistem resirkulasi. Infeksi bakteri ini berkaitan dengan kondisi stress akibat: kepadatan tinggi, malnutrisi, penanganan yang 
kurang baik, bahan organik tinggi, oksigen rendah, kualitas air yang buruk, fluktuasi suhu air yang ekstrim, dll.

e. Gejala Klinis: Nafsu makan menurun, lemah, tubuh berwarna gelap, dan pertumbuhan lambat. Warna gelap di bawah rahang, mata menonjol, pendarahan, perut gembung (dropsy) atau luka yang berkembang menjadi borok. Sering pula infeksi Streptococcus spp. tidak menunjukkan gejala klinis yang jelas kecuali kematian yang terus berlangsung. Pergerakan tidak terarah (nervous) dan pendarahan pada tutup insang (operculum). Sering pula ditemukan bahwa ikan yang terinfeksi terlihat normal sampai sesaat sebelum mati.

\section{Penyakit Mycobacteriosis/Fish TB}

a. Penyebab Mycobacterium marinum (air laut) dan $M$. fortuitum (air tawar)

b. Karakteristik patogen: Bakteri gram positif, berbentuk batang pendek dan non-motil;

c. Infeksi Mycobacterium banyak dilaporkan pada ikan yang dipelihara pada lingkungan perairan tenang (stagnant) dan sistem resirkulasi, sehingga jenis ikan seperti gurame dan cupang yang cocok pada kondisi tersebut sering dilaporkan terinfeksi penyakit tersebut. Kolam tadah hujan dan pekarangan dengan sumber air terbatas lebih rentan terhadap infeksi jenis penyakit ini. Ikan yang terinfeksi Mycobacterium menunjukkan gejala yang variatif, namun sering pula tidak menunjukkan gejala klinis sama sekali. Pola serangan mycobacteriosis bersifat kronik - sub akut, baik pada ikan air tawar, payau maupun ikan air laut. Suhu optimum berkisar $25-35{ }^{\circ} \mathrm{C}$, tetapi masih dapat tumbuh baik pada suhu $18-20^{\circ} \mathrm{C}$.

d. Gejala Klinis: Hilang nasfu makan, lemah, kurus, mata melotot (exopthalmia) serta pembengkakan tubuh. Apabila menginfeksi kulit, timbul bercakbercak merah dan berkembang menjadi luka, sirip dan ekor geripis. Pada fase infeksi lanjut, secara internal telah terjadi pembengkakan empedu, ginjal dan hati, serta 


\begin{abstract}
sering ditemukan adanya tubercle/nodule yang berwarna putih kecoklatan. Gejala penyakit mycobacteriosis tidak selalu tampak, dan bervariasi antar individu ikan yang terserang. Pertumbuhan lambat, warna pucat dan tidak indah terutama untuk ikan hias. Lordosis, skoliosis, ulser dan rusaknya sirip (patah-patah) dapat terjadi pada beberapa ekor ikan yang terserang.
\end{abstract}

\section{BacterialFin/Tail}

\section{Rot/Pseudomoniasis}

a. Penyebab Pseudomonas spp.

b. Karakteristik patogen: Merupakan bakteri gram negatif dan nonspora. Bakteri ini bersifat aerobik, dengan ukuran $3 \mu \mathrm{m} x$ 0,5 $\mu \mathrm{m}$, motil, memproduksi pigmen fluorescent, dan berkembang biak di tanah dan air. Penyakit pseudomoniasis merupakan penyakit bakterial yang sering terjadi pada semua umur dan jenis ikan, baik ikan air tawar maupun air laut. Pseudomonas ini merupakan agen penyakit yang berbahaya terutama pada ikan air tawar serta dapat berakibat kematian yang tinggi karena penyakit ini menular dalam waktu cepat bila kondisi perairan memungkinkan. Penularan serta penyebaran penyakit pseudomoniasis adalah kontak langsung dengan ikan yang sakit atau dengan lingkungan yang tercemar.Serangannya bisa terjadi kalau ikan rentan atau lemah akibat lapar, pakan tidak cocok, dingin, atau kondisi air tidak baik.

c. Gejala Klinis: Ikan lemah bergerak lambat, bernafas megapmegap di permukaan air. Warna insang pucat dan warna tubuh berubah gelap. Terdapat bercakbercak merah pada bagian luar tubuhnya dan kerusakan pada sirip, insang dan kulit. Mula-mula lendir berlebihan, kemudian timbul perdarahan. Sirip dan ekor rontok (membusuk). Perdarahan, perut ikan menjadi kembung yang dikenal dengan dropsy.

6. Edwarsiellosis

a. Penyebab Edwarsiella tarda

b. Karakteristik patogen: E. tarda berbentuk batang bengkok, bersifat gram negatif bergerak dengan bantuan flagella, tidak 
membentuk spora atau kapsul, bersifat fakultatif anaerob, dan mampu memproduksi H2S. Bakteri ini dapat dijumpai di lingkungan air tawar dan air laut, menginfeksi beberapa jenis ikan antara lain: salmon, catfish, ikan mas, nila, dll. Beberapa inang alamiah bisa bertahan sebagai carrier. Penularan secara horizontal yaitu kontak antara inang satu dengan inang lainnya atau melalui air. Kasus edwardsiellosis umumnya terjadi pada suhu air yang relatif tinggi $\left( \pm 30^{\circ} \mathrm{C}\right)$ dan kandungan bahan organik tinggi. Tingkat kematian tergantung pada kondisi lingkungan, pada kondisi yang sangat buruk dapat mengakibatkan kematian hingga $50 \%$.

c. Gejala Klinis: Gejala eksternal ikan yang terserang edwardsiellosis pada infeksi ringan, hanya menampakkan luka-luka kecil. Sebagai perkembangan penyakit lebih lanjut, luka bernanah berkembang dalam otot rusuk dan lambung. Pada kasus akut akan terlihat luka bernanah secara cepat bertambah dengan berbagai ukuran. Pucat, perut gembung berisi cairan yang berwarna kekuningan atau kemerahan, pendarahan pada anus dan/atau anus tertekan ke dalam, dan mata pudar. Perkembangan lebih lanjut, luka-luka (rongga-rongga) mengalami pembeng-kakan adn apabila digores akan tercium bau gas $\mathrm{H}_{2} \mathrm{~S}$.

\section{Enteric Septicemia of Catfish}

(ESC)

a. Penyebab Edwarsiella ictaluri

b. Karakteristik patogen: $E$. ictaluri berbentuk batang, bersifat gram negatif bergerak dengan bantuan flagella, tidak membentuk spora atau kapsul dan bersifat fakultatif anaerob. Bakteri ini awalnya diketahui menginfeksi ikan cannel catfish, namun belakangan diketahui dapat menginfeksi jenis ikan lainnya seperti: lele, patin, dan sidat. Secara eksperimental, beberapa jenis ikan seperti trout, nila, salmon dan ikan hias juga dapat terinfeksi jenis bakteri ini. 
Penularan secara horizontal yaitu kontak antara inang satu dengan inang lainnya atau melalui air. Kasus ESC umumnya terjadi pada saat suhu air relatif hangat $\left(22-28^{\circ} \mathrm{C}\right)$, namun pada saat suhu air di bawah $20^{\circ} \mathrm{C}$ atau di atas $30^{\circ} \mathrm{C}$, keganasan bakteri ini sangat menurun.

c. Gejala Klinis: Lemah, hilang nafsu makan, warna insang pucat, terkadang mata menonjol dan/ atau perut bengkak (dropsy). Sering pula ditemukan adanya petechiae (bintik-bintik merah) pada bagian tubuh yang tidak berpigmen (di bawah dagu, perut atau di pangkal sirip). Berenang di permukaan air atau di tepi kolam dengan kepala mengarah ke atas. Sebelum mati, biasanya ikan berenang seperti kejang dan/atau berenang berputar seperti spiral. Terdapat bercak-bercak putih pada organ dalam (hati, limfa, ginjal, dll.).

8. Vibriosis pada ikan a. Penyebab Vibrio alginolyticus, $V$. parahaemolyticus, $\quad V$. vulnificus, $V$. ordalii

b. Karakteristik patogen:

Merupakan bakteri pada ekosistem air laut, dan vibirosis masih merupakan masalah utama bagi industri budidaya ikan laut. Kasus vibriosis dapat terjadi sepanjang tahun, namun umumnya terkait dengan stress akibat penanganan, kepadatan tinggi ataupun perubahan cuaca yang ekstrim. Tingkat kematian ikan pada stadia larva hingga ukuran fingerling yang terserang bakteri ini dapat mencapai 80-90\%.

c. Gejala Klinis : Lemah, hilang nafsu makan, berenang di permukaan air, dan warna kulit buram. Inflamasi pada anus, insang, mulut, pangkal sirip, yang diikuti dengan perdarahan dan lepuh pada permukaan tubuh, serta luka terbuka. Pada infeksi lanjut terjadi perdarahan pada mulut dan pangkal sirip, ekses lendir pada insang, dropsy, warna hati pucat, dan mata membengkak. 
Cara kerja ( Rahayu et al., 2019).

1. Persiapan Alat dan Bahan Semua peralatan yang digunakan seperti cawan petri, tabung reaksi, erlenmeyer, di bungkus dengan kertas dan dimasukkan ke dalam autoklaf dengan suhu $121^{\circ} \mathrm{C}$ dan tekanan 1 atm selama 15 menit. Sedangkan alat pembedahan cukup dengan menyemprotkan alkohol 70 $\%$ dengan tujuan agar alat dalam kondisi steril (Champbell and Reece, 2005).

2. Pembuatan Media yaitu dengan cara menimbang media kemudian dimasukkan kedalam tabung erlenmeyer dan ditambahkan aquades. Media tersebut dipanaskan pada hot plate sambil diaduk hingga mendidih agar media tersebut homogen. Kemudian ditutup menggunakan aluminium foil dan dilakukan sterilisasi dengan autoclave. Proses sterilisasi dilakukan menggunakan autoclave dengan suhu $121^{\circ} \mathrm{C}$ tekanan $1 \mathrm{~atm}$ selama 15 menit. Setelah dilakukan sterilisasi media di tunggu sampai suhunya menurun sekitar $50{ }^{\circ} \mathrm{C}$, kemudian dapat di tuang ke cawan petri atau tabung reaksi dan disimpan di lemari pendingin.

3. Persiapan Sampel

Uji Sampel ikan yang digunakan dilakukan pemeriksaan gejala klinis. Parameter pemeriksaan gejala klinis pada bagian tubuh ikan, seperti mulut, sisik, perut dan insang ikan. Kemudian dilakukan uji laboratorium. Pengambilan organ target harus berdasarkan pada sifat HPIK dalam menginfeksi organ inang/carrier nya. Organ yang diambil untuk pemeriksaan bakteri antara lain ginjal, hati, limpa, mata maupun otak ikan (ukuran ikan > 6 cm), sedangkan ikan kecil (juvenile/sac fry) yang berukuran < $3 \mathrm{~cm}$ adalah keseluruhan bagian tubuh dengan cara digerus.

4. Isolasi Bakteri Isolasi bakteri dilakukan dengan mengambil isolat dari ginjal ikan karena ada bakteri tertentu yang terdapat didalam darah. Setelah mendapatkan organ target maka organ diambil menggunakan jarum ose steril lalu ditanam pada media TSA. Langkah selanjutnya diinkubasi selama 18-24 jam dengan suhu $37^{\circ} \mathrm{C}$. Kemudian setelah diinkubasi harus 
dilakukan pemurnian dengan cara mengambil koloni target dari bakteri dan ditanam pada media TSA baru kemudian $30^{\circ} \mathrm{C} \pm 2{ }^{\circ} \mathrm{C}$ selama 18-24 jam. Uji Presumtif dan Biokimia Bakteri Uji presumtif untuk menentukan sifat dasar dari mikroba yang diuji, dilakukan sebagai langkah karakterisasi umum dari bakteri yang terdiri dari uji gram, uji katalase, dan uji oksidase (Saputri dkk., 2016). Sedangkan uji biokimia dilakukan untuk mengetahui ciri fisiologis atau biokimia bakteri karena kemungkinan bakteri yang morfologinya sama memerlukan nutrisi dan persyaratan lingkungan yang mempunyai sifat biokimia yang berbeda. Hal ini sesuai dengan pernyataan Saputri dkk., (2016), bahwa uji biokimia ini dilakukan untuk menentukan genus dan jenis spesies. Uji biokimia terdiri dari uji TSIA, LIA, MIO, Urea,

Gelatin Simmons Citrat, MR-VP, gula-gula dan $\mathrm{O} / \mathrm{F}$.

5. Identifikasi Bakteri Identifikasi jenis bakteri dengan cara menyesuaikan hasil pengujian dan karakteristik bakteri yang sudah tersedia pada lembar identifikasi dengan menggunakan buku Biochemichal Tests for Identification of Medical Bacteria (Mac Faddin, 1980), buku Manual for the Identification of Medical Bacteria (Cowan and Steel's, 1993), Bergey's Manual of Determinative Bacteriology.

6. Parameter Pengamatan dan Analisa Data Parameter yang diamati yaitu gejala klinis eksternal dan internal pada ikan. Gejala klinis eksternal di lakukan dengan mengamati bagian tubuh luar ikan seperti sirip geripis, perut membengkak, sisik lepas, warna tubuh pucat, luka, mata menonjol (exphthalmia) dan lain sebagainya, sedangkan patologi internal yaitu dengan mengamati organ seperti hati pucat, kerusakan ginjal, pendarahan dan kerusakan organ dalam lainya. Data yang diperoleh kemudian dianalisa secara deskriptif .

\section{Waktu dan Tempat}

Penelitian ini dilaksanakan di bulan September - November 2019 di Laboratorium Mikrobiologi Program studi D-III Analis Kesehatan STIKES 
Borneo Cendekia Medika Pangkalan Bun.

\section{HASIL DAN PEMBAHASAN}

Warna tubuh kusam/gelap, nafsu makan menurun, mengumpul dekat saluran pembuangan, kulit kasat, dan ekses lender. Perdarahan pada pangkal sirip, ekor, sekitar anus dan bagian tubuh lainnya Sisik lepas, luka di sekitar mulut, dan bagian tubuh lainnya. Perut lembek dan bengkak (dropsy) yang berisi cairan merah kekuningan. Bakteri penyebabnya adalah Aeromonas hydrophila.

Menurut (Dinlut, 2017) Infeksi bakteri ini biasanya berkaitan dengan kondisi stress akibat: kepadatan tinggi, malnutrisi, penanganan yang kurang baik, infeksi parasit, bahan organik tinggi, oksigen rendah, kualitas air yang buruk, fluktuasi suhu air yang ekstrim. Serangan bersifat akut, dan apabila kondisi lingkungan terus merosot, kematian yang ditimbulkannya bisa mencapai $100 \%$. Gejala klinis - Luka di sekitar mulut, kepala, badan atau sirip. Luka berwarna putih kecoklatan kemudian berkembang menjadi borok. Infeksi di sekitar mulut, terlihat seperti diselaputi benang (thread-like) sehingga sering disebut penyakit“jamur mulut". Di sekeliling luka tertutup oleh pigmen berwarna kuning cerah. Apabila menginfeksi insang, kerusakan dimulai dari ujung filamen insang dan merambat ke bagian pangkal, akhirnya filamen membusuk dan rontok (gill rot).

Selain itu terdapat ikan yang berwarna gelap di bawah rahang, mata menonjol, pendarahan, perut gembung (dropsy) atau luka yang berkembang menjadi borok. Pergerakan tidak terarah (nervous) dan pendarahan pada tutup insang (operculum). Sering pula ditemukan bahwa ikan yang terinfeksi terlihat normal sampai sesaat sebelum mati bakteri yang menginfeksi adalah Streptococcus agalactiae.

Ditemukan juga ikan lemah bergerak lambat, bernafas megapmegap di permukaan air. Warna insang pucat dan warna tubuh berubah gelap. Terdapat bercak-bercak merah pada bagian luar tubuhnya dan kerusakan pada sirip, insang dan kulit. Mula-mula lendir berlebihan, kemudian timbul perdarahan. Sirip dan ekor rontok (membusuk). Perdarahan, perut ikan menjadi kembung yang dikenal dengan dropsy. Penyebabnya adalah Pseudomonas spp. Merupakan bakteri gram negatif dan nonspora. Bakteri ini bersifat aerobik, dengan ukuran $3 \mu \mathrm{m} x$ 
0,5 $\mu \mathrm{m}$, motil, memproduksi pigmen fluorescent, dan berkembang biak di tanah dan air. Penyakit pseudomoniasis merupakan penyakit bakterial yang sering terjadi pada semua umur dan jenis ikan, baik ikan air tawar maupun air laut. Pseudomonas ini merupakan agen penyakit yang berbahaya terutama pada ikan air tawar serta dapat berakibat kematian yang tinggi karena penyakit ini menular dalam waktu cepat bila kondisi perairan memungkinkan. Penularan serta penyebaran penyakit pseudomoniasis adalah kontak langsung dengan ikan yang sakit atau dengan lingkungan yang tercemar. Serangannya bisa terjadi kalau ikan rentan atau lemah akibat lapar, pakan tidak cocok, dingin, atau kondisi air tidak baik.

\section{KESIMPULAN}

Perlu dilakukan penelitian lebih lanjut mengenai jenis bakteri yang menginfeksi spesies ikan yang lainnya

\section{DAFTAR PUSTAKA}

Dinas Kelautan dan Perikanan. 2017. Buku Saku Hama Dan Penyakit Ikan. Kebumen.
Listyanto, N dan S. andriyanto. 2009. Ikan Gabus (Channa striata) Manfaat Pengembangan dan Alternatif Teknik Budidayanya. Media akuakultur. 4 (1): 18-25. Setiawan, M.R., Dewi dan Oktaviyanti, I.K. 2015. Ekstrak Ikan Haruan (Channa striata) Meningkatkan Jumlah Neokapiler Pada Penyembuhan Luka (Extract Of Haruan (Channa striata) Increases Neocapillaries Count In Wound Healing Process). Dentofasial. 14 (1): 1-5. 